\title{
MORAL EMOTIONS AND SELF-MONITORING
}

\author{
GÜLÇIMEN YURTSEVER
}

Çă̆ University

\begin{abstract}
This study offers a set of relationships between self-monitoring and two moral emotions: shame and guilt. After creating various combinations of relationships between the behavioral manifestations of shame and guilt and the sub-dimensions of self-monitoring, these relationships are tested with data obtained from lower level managers in a public bank in Turkey. Results show that there are positive relationships between these constructs. The implications of these findings for understanding moral emotions and self-monitoring were also considered, along with some potential applications.
\end{abstract}

Key words: self-monitoring, guilt, shame, business ethics, moral emotions.

\section{AHLAKİ DUYGULAR VE KENDI KENDINI DENETIM}

\section{ÖZET}

Bu çalışmada, kendi kendini denetim ile ahlaki duygular arasındaki ilişki araştırılmıştır. Ahlaki duygular, suçluluk ve utanma duygusu olarak araştırılmıştır. Veriler, Türkiye'de bir kamu bankasında çalışan alt derecedeki yöneticilerden elde edilmiştir. Suçluluk ve utanma ile kendi kendini denetim arasında pozitif ilişki ortaya çıkmıştır. Ayrıca, araştırmanın sonuçları tartışılmış, uygulamacılar için öneriler sunulmuştur.

Anahtar kelimeler: kendi kendini denetim, suçluluk, utanma, ahlaki duygular.

In this study the relationship between moral emotions and self-monitoring is examined. In order to clarify how we conceptualize the relationship between these two constructs, it is necessary to understand the role of emotions in business life and, consequently, the development and the importance of the concept of self-monitoring.

The amount of business literature on emotion has flourished in recent years. Lurie (2004) argues that having emotions is an important ethical asset for business managers and is central to humanizing management. Emotions are "processes of evaluation leading to representations and feelings that involve calls for action that incite urges, or plans, for action" (Frijda, 1986). Emotions can be divided into: basic emotions (e.g., joy, love, anger) and social emotions (e.g., moral emotions) (Thoits, 1989).

* Gülçimen Yurtsever is an Associate Professor in the Department of Management at Çă̆ University, 33800, Yenice, Tarsus/Mersin, Turkey. E-mail: gulcimenyurtsever@mynet.com 
Moral emotions (e.g., shame and guilt) are an important factor in understanding moral motivations and behavior. Moral emotions are among the most important factors in social judgment, which arises from the existing gap between moral consideration or the response of morality and moral standard (James, 1948; Harrison, 1984).

Human behavior theorists have long been interested in describing the way people behave in social contexts. Sociologist Goffman (1956) proposed that individuals use social cues to monitor their behavior in order to give appropriate impressions to society. Snyder later (1974) conceptualized these individual differences in his theory of "self-monitoring." This theory proposed that individual differences are either "high" or "low" self-monitoring depending on their situational behavior. "High self-monitoring" reflects sensitivity to cues about the appropriateness of one's social behavior. High self-monitors have the ability to use these cues as guidelines for their behavior. In contrast, "low selfmonitors" are less aware of situational norms and less concerned with them. They use their own attitudes and emotions to guide behavior. They have little need to attend to cues inherent in each situation; and, in fact, research indicates that they diagnose such information quite inaccurately (Snyder, 1987).

The essence of self-monitoring is to have the ability to maneuver through social situations based on one's ability to predict social cues. High self-monitors determine behavioral appropriateness from the views of others in a given situation and then enact this behavior (Snyder and Gangestad, 1982).

For many years, there has been a continuing suggestion in the literature that moral emotion is generated virtually by the constant monitoring of the self in relation to society (e.g., Cooley, 1982; Goffman, 1967; Scheff, 1988). For example, shame is a moral emotion arising as a result of self-

\section{Figure 1}

The Relationship between Moral Emotions and Self-Monitoring

\begin{tabular}{|c|c|}
\hline Moral emotions & Self-monitoring \\
\hline 1) Shame & \\
\hline \multirow{2}{*}{$\begin{array}{l}\text { Social impropriety (e.g., your home is } \\
\text { very messy and unexpected guests arrive) }\end{array}$} & \\
\hline & \multirow[t]{2}{*}{$\begin{array}{l}\text { Extraversion (e.g., being the center of } \\
\text { attention) }\end{array}$} \\
\hline $\begin{array}{l}\text { Exposed inadequacy (e.g., strongly defending } \\
\text { a point of view in a discussion to learn you } \\
\text { were incorrect) }\end{array}$ & \\
\hline 2) Guilt & \multirow{2}{*}{$\begin{array}{l}\text { Acting (e.g., entertaining and speaking } \\
\text { public) }\end{array}$} \\
\hline $\begin{array}{l}\text { Impersonal transgression (e.g., successfully lying } \\
\text { about your qualifications to get a job) }\end{array}$ & \\
\hline $\begin{array}{l}\text { Harm another person (e.g., as manager, retaining } \\
\text { working conditions known to be harmful to your } \\
\text { employees' health) }\end{array}$ & $\begin{array}{l}\text { Other-directedness (e.g., looking to the } \\
\text { behavior of others for cues) }\end{array}$ \\
\hline $\begin{array}{l}\text { Trust violation (e.g. giving false testimony at a } \\
\text { trial though you are not caught) }\end{array}$ & \\
\hline
\end{tabular}


monitoring (Lewis, 1971). Therefore, there may be a relationship between self-monitoring and feelings of shame and feelings of guilt, which is what we are investigating in this study. The relationships in this study are illustrated in Figure 1 and discussed below.

\section{SHAME AND SELF-MONITORING}

Shame generally results from the existence of a real or imaginary audience for one's wrongdoing (Johnson et al., 1987). The real or imaginary audience shapes people's behavior. The main reason for feeling shame is the reaction to criticism from others and a fear of rejection, loss of social affection or the withdrawal of love (Glenn and Glenn, 1982). The idea of shame is based on the moral standards within society. Therefore, shame is a learned emotional sensitivity by the experience that individuals have within the norms of a society. James (1948) stated that if people sense the difference between their current self-state and the social ideal, they experience shame.

The moral meaning of shame appears when the individual experiences shame which, in turn, reinforces its effectiveness in conducting appropriate behavior. The individual decides on the basis of personal values by taking into account the social norms and cues. Potentially shut out by feelings of shame, individuals may create a freedom for their action. The result is that they may not maintain interpersonal relationships because society is interdependent through values and responsive manner.

Similarly, high self-monitors recognize and regulate their behavior by taking into account the social norms. Their behavior is guided primarily by group norms, roles and other features of the social situation. They adopt and control their behavior according to the social expectation (Anderson and McLenigan, 1987). Controlling the behavior makes people more cautious. They try to reflect the believability of their claims by presenting information about their own qualities, accomplishments, and adequacy. If they fail to reflect their claims, they tend to experience shame (Paulhus, 1982).

From the reasoning outlined above, the following hypotheses were derived.

HI: There is positive relationship between shame and self-monitoring.

Hla: There is a positive relationship between shame from social impropriety and self-monitoring.

$H 1 b$ : There is a positive relationship between shame from social impropriety and other-directedness. Hlc: There is a positive relationship between shame from social impropriety and the acting dimension.

H1d: There is a positive relationship between shame from social impropriety and extroversion.

H1e: There is a positive relationship between shame from exposed inadequacy and self-monitoring.

HIf: There is a positive relationship between shame from exposed inadequacy and otherdirectedness.

H1g: There is a positive relationship between shame from exposed inadequacy and the acting dimension.

H1h: There is a positive relationship between shame from exposed inadequacy and extroversion.

\section{GUILT AND SELF-MONITORING}

Guilt also is a moral emotion that arises from the discrepancy between individual moral behavior and moral standards. Unlike the compulsion to isolate oneself elicited by shame, guilt tends to be more 
restricted to an unfair act and the concern for its rectification. Guilt refers to a feeling of negative selfregard associated with the real or an imaginary commission of an act without any need for an audience (Johnson et al., 1987). Guilt is outward-focused and is about responsibility and caring feelings for others (Tangney, 1992).

During a guilt experience, individuals focus on a specific behavior (Lewis, 1971). The influence of society here is that it guides individuals on what is right or wrong. Therefore, when feeling guilt over a specific behavior, people may judge moral issues in the context of social norms and the situational context. When their action or behavior fails their judgment, they may actively work at creating feelings of guilt because of their effectiveness at finding appropriate action (Mondata, 1993). Individuals develop impersonal procedures for establishing the truth and they put ideas into judgment. Therefore, guilt has a moral meaning because it originates from the perception of the situation as guided by the individual's concern with morality.

Essentially, guilt is in relationship to feelings or with to awareness of other people's feelings, beliefs and needs and may include taking initiatives in judgment to meet such needs. Critical thinking is needed for understanding how to access other people's knowledge (Elbow, 1973). Previous research also has found guilt significantly correlated with good social judgment (Tangney, 1992, 1995; Tangney et al., 1992). Similarly, high self-monitors evaluate their behavior by applying situational appropriateness and social norms. High self-monitors are sensitive to and accurate in diagnosing social cues in each situation (Ajzen et al., 1982). In contrast, low self-monitors do not evaluate the event within the social context. They display their attitudes and values consistently from one situation to another (Head, 1998). These individuals are less aware of situational norms, less responsive to interpersonal cues and less concerned about socially appropriate behavior. They may find a reason that fits their inner state.

One of the key mechanisms in monitoring behavior is self-judgment. Self-judgment is a mechanism that provides a balance among the various aspects of others and ourselves. Self-monitors judge behavioral appropriateness from the perspectives of others and enact these behaviors (Cooley, 1982). From the reasoning outlined above, relationship between guilt and self-monitoring has been hypothesized:

H2: There is positive relationship guilt and self- monitoring.

H2a: There is a positive relationship between guilt from impersonal transgression and selfmonitoring.

H2b: There is a positive relationship between guilt from impersonal transgression and otherdirectedness.

H2c: There is a positive relationship between guilt from impersonal transgression and the acting dimension.

H2d: There is a positive relationship between guilt from impersonal transgression and extroversion.

H2e: There is a positive relationship between guilt from harm to another person and self-monitoring.

H2f: There is a positive relationship between guilt from harm to another person and otherdimensions.

H2g: There is a positive relationship between guilt from harm to another person and acting dimensions.

H2h: There is a positive relationship between guilt from harm to another person and extroversion. 
H2i: There is a positive relationship between guilt from trust violation and self-monitoring.

H2j: There is a positive relationship between guilt from trust violation and other-directedness.

$H 2 k$ : There is a positive relationship between guilt from trust violation and the acting dimension.

H2l: There is a positive relationship between guilt from trust violation and extroversion.

\section{METHODS}

\section{Sample}

The sample in this study consisted of 102 lower-level managers of a bank in Turkey. The subjects were participants in management development seminars sponsored by their bank. Ninety managers participated in this study. All were university graduates and had at least 10 years of work experience. The average age of the participants was 32 . The sample was chosen because the participants were from several cities throughout Turkey enrolled in the course.

\section{Measures}

The measure of self-monitoring used in this study was developed by Snyder (1974). This scale consists of a 25-item self-descriptive statement. However, where the self-monitoring scale was factor analyzed three subscales were identified. The results from the studies indicated that seven items did not load any of the three factors (Briggs, Cheek, 1986; Gudyskunst et al., 1985). The three selfmonitoring subscales are extroversion, acting and other-directedness. The scale used in this study consists of 18 items (see Appendix A). Snyder's scale was used because it continues to stimulate the research related to self-monitoring (e.g., Leone and Corte, 1994; Norris and Zweigenhaft, 1999; Schlenker and Weigold, 1992). A five-point scale was used to compute the scoring format. This scale has endpoints labeled "Very True," "Very Characteristic of Me," "Very False of Me," and "Very Uncharacteristic of Me."

The measure of shame and guilt measured by using the dimension of conscience questionnaire (DCQ) developed by Johnson et al. (1989). The DCQ provides a measure of both shame and guilt with construct validity and reliability (Johnson et. al., 1989; Gore and Harvey, 1995; Harvey et al., 1998). The DCQ consists of 30 brief scenarios (see Appendix B). Fifteen items of the DCQ were designed to measure shame and another 15 items measure guilt. It is composed of five clusters of scenarios (Gore and Harvey, 1995; Harvey et al., 1997). Three clusters are found to arouse guilt: Impersonal transgression, harm another person and trust violation. The other two clusters are found to arouse shame: social impropriety and exposed inadequacy. A five-point scale was used to compute the scoring format. This scale has endpoints labeled "Feel Kind of Good," and "Feel Very Bad."

These original items were translated into Turkish and then back to English by different translators to ensure the accuracy of meaning. Then, the Turkish versions were checked by a committee of Turkish psychologists and sociologists who deemed the items to be appropriate for application in Turkey.

\section{RESULTS}

The coefficient alpha was computed as a measure of internal consistency reliability for the scales. The alpha reliability of self-monitoring was .95 . The alpha reliabilities of three subscales of self- 
monitoring were: Other-Directedness, Acting Dimension and Extraversion to be .90, .77 and .89, respectively. The alpha reliabilities of the five clusters of the DCQ were: Social Impropriety, Exposed Inadequacy, Impersonal Transgression, Harm to Another Person and Trust Violation to be .80, .89, $.83, .78$ and .77 , respectively.

The hypotheses formulated in this study were the existence of a positive relationship between shame from social impropriety and exposed inadequacy, and self-monitoring and its subscales. The results in Table 1 below show that there were significant positive relationships between shame from social impropriety and exposed inadequacy, and self-monitoring and its subscales. Thus, the hypotheses formulated in this study are confirmed. It should be noted that the relationship of social impropriety and impersonal transgression is weak in terms of the variance accounted for, but suggestive as to the direction of effects. Others hypotheses stated in this study were that there were positive relationships between guilt from impersonal transgression, harm to another person and trust violation and selfmonitoring and its subscales. The results of this study in Table 1 indicate that there were significant positive relationships between guilt from impersonal transgression, harm to another person, trust violation and self-monitoring and its subscales. However, the relationships here between trust violation and self-monitoring and its subscales are very weak in terms of the variance accounted for $(\mathrm{P}<02)$, but suggestive as to direction of efforts.

Table 1

Moral Emotions and Self-Monitoring (Mean, Standard Deviations and Pearson Correlation Coefficients)

\begin{tabular}{|c|c|c|c|c|c|c|}
\hline & \multirow[b]{2}{*}{$\mathbf{M}$} & \multirow[b]{2}{*}{ SD } & \multicolumn{4}{|c|}{ Self-Monitoring } \\
\hline & & & SM & $\begin{array}{l}\text { Other } \\
\text { Directedness }\end{array}$ & $\begin{array}{l}\text { Acting } \\
\text { Dimension }\end{array}$ & Extraversion \\
\hline M & & & 96 & 39 & 16 & 20 \\
\hline SD & & & 19 & 8 & 3 & 4 \\
\hline \multicolumn{7}{|l|}{ DCQ Scenario Cluster } \\
\hline Shame & 50 & 14 & $.40^{* *}$ & $.39 * *$ & $.42 * *$ & $.29 * *$ \\
\hline Social-impropriety & 31 & 10 & $.32 * *$ & $.30 * * * *$ & $.36^{*}$ & $.23 * * *$ \\
\hline Exposed inadequacy & 16 & 5 & $.49 *$ & $.47 *$ & $.47 *$ & $.37 *$ \\
\hline Guilt & 43 & 11 & $.33 * *$ & $.31 * * *$ & $.32 * *$ & $.29 * *$ \\
\hline Impersonal transgression & 16 & 5 & $.31 * *$ & $.30 * *$ & $.31 *$ & $.29 * * * *$ \\
\hline Harm to another person & 18 & 4 & $.48 *$ & $.45^{*}$ & $.43^{*}$ & $.45^{*}$ \\
\hline Trust violation & 9 & 3 & $.24 * *$ & $.23 * * *$ & $.22 * * *$ & $.23 * * *$ \\
\hline
\end{tabular}

Note: All tests are one tailed

$* \mathrm{P}<.01 ; * * \mathrm{P}<.02 ; * * * \mathrm{P}<.03 ; * * * * \mathrm{P}<.05$.

\section{CONCLUSIONS}

This study investigated the relationship between self-monitoring and moral emotions. The results showed that there is a positive relationship between self-monitoring and feelings of shame. The main 
reason for this may be that an appropriate impression on the society is very important for high selfmonitors. To maintain their status in the eyes of a reference group and live up to the expectations held by society make people more cautious. When they fail to meet social expectation, they may produce feelings of shame. Furthermore, high self-monitors may be more attentive and knowledgeable as to their own behavior and social behavior than low self-monitors may be. This also may reflect in the effects of accessibility on social interpretations. They may predict their own behavior as if in the eyes of another. Therefore, they may shape or change their behavior. Or they may not perform the unethical behavior.

A positive relationship was also found between self-monitoring and feelings of guilt. They may be conscious of both their feelings and their judgments, consistent with deservedness of the other. They may integrate their feelings with thinking and have a high tolerance for internal contradiction. Low self-monitors, on the other hand, may keep their beliefs and social norms separate. Therefore, they may not see any discrepancy between their beliefs and social norms. They may generate reasons consistent more with their beliefs than social reality.

The result may have important implications for business. The results suggest that self-monitoring may contribute to producing moral emotions. Thus, appraising moral emotions in one's self and others may require adequate social functioning. Therefore, trainers need to emphasize social monitoring of one's self. They also need to emphasize the process of integrating one's feelings and one's judgments consistent with the deservedness of the other. It should not be assumed that every experience of moral emotion provides benefits in organizational life or the individual's performance. If the experience of moral emotions is linked to irrational beliefs, they may be maladaptive.

A limitation of this study is that the data were obtained from managers of a bank. It is possible that these results might not generalize to a broader population. Other studies looking at the relationship between these variables should be conducted using different samples. Despite this limitation, the relationship between moral emotion and self-monitoring adds to the understanding of why individuals produce moral emotions. Practically such knowledge may help moral emotion training for professionals.

\section{REFERENCES}

Ajzen, I., Timko, C. and White, J.B. (1982). "Self-Monitoring and Attitude Behavior Relation," Journal of Personality and Social Psychology, 42: 426-435

Anderson, C.R. and McLenigan, M.M. (1987). "Sex Differences in the Relationship between SelfMonitoring and Leader Behavior," Small Group Behavior, 18: 147-167.

Briggs, S.R. and Cheek, J.M. (1986). "The Role of Factor Analysis in the Development and Evaluation of Personality Scales," Journal of Personality, 54: 106-148.

Cooley, C.H. (1982). Human Nature and the Social Order. New York: Scribners.

Elbow, P. (1993). Writings without Teacher. London: Oxford University Press. 
Frijda, N. H. (1986). The Emotions. Cambridge, UK: Cambridge University Press.

Glenn, E.S. and Glenn, C.G. (1982). Man and Mankind: Conflict and Communication between Cultures. Norwood, NJ. Ablex.

Goffman, E. (1956). The Presentation of Self in Everyday Life. Edinburgh: University of Edinburgh Press.

----- (1967). Interaction Ritual. New York: Anchor.

Gore, E. and Harvey, O.J. (1995). "A Factor Analysis of a Scale of a Shame and Guilt: Dimensions of Conscience Questionnaire," Personality and Individual Differences, 19 (5): 769-771.

Gudykunst, W.B., Yang, S.M. and Nishida, T. (1985). "Cultural Differences in Self-Consciousness and Self-Monitoring," Communication Research, 14: 7-34.

Harrison, B. (1984). “Moral Judgment, Action and Emotion,” Philosophy, 59: 294-321.

Harvey, O.J., Gore, E.J., Frank, H. and Batres, A.R. (1997). "Relationship of Shame and Guilt to Gender and Patenting Practices," Personality and Individual Differences, 23(1): 135-146.

Head, T.C. (1998). "Roles of Self-Monitoring and Situations Ambiguity in the Social Information Processing Model," Psychological Report, 83: 1447-1453.

James, W. (1948). Psychology. New York: World (Original work published, 1890).

Johnson, R.C., Danko, G.P., Huang, Y., Park, J.Y., Johnson, S.B. and Nogoshi, C.T. (1987). "Guilt, Shame and Adjustment in Three Cultures," Personality and Individual Differences, 8: 357-364.

Johnson, R.C., Kim, R.J. and Danko, G.P. (1989). "Guilt, Shame and Adjustment: A Family Study," Personality and Individual Differences, 10: 71-74.

Leone, C. and Corte, V. (1994). "Concern for Self-Presentation and Self-Congruence; SelfMonitoring, Machiavellianism and Social Conflict," Social Behavior and Personality, 22 (4): 305312.

Lewis, H.B. (1971). Shame and Guilt in Neurosis. New York: International University Press.

Lurie, Y. (2004). "Humanizing Business through Emotions: On the Role of Emotions in Ethics," Journal of Business Ethics, 49: 1-11

Mondata, L. (1993). "Understanding Oughts by Assessing Moral Reasoning or Moral Emotions," in G.G. and T.E. Wren (eds.), The Moral Self: 292- 309, Cambridge, MA: MIT Press.

Norris, S.C. and Zweigenhaft, R.L. (1999). "Self-Monitoring, Trust and Commitment in Romantic Relationship," The Journal of Social Psychology, 139(2): 215-220. 
Paulhus, D. (1982). "Individual Differences, Self-Presentation and Cognitive Dissonance: Their Concurrent Operation in Forced Compliance," Journal of Personality and Social Psychology.

Scheff, T.J. (1988). "Shame and Conformity: The Deference-Emotion System," American Sociological Review, 53: 395-406.

Schlenker, B.R. and Weigold, M.F. (1992). "Interpersonal Processes Involving Impression Regulation and Management," Annual Review Psychology, 43: 133-168.

Snyder, M. (1987). Public Appearances, Private Realizes. San Francisco: Freeman.

Snyder, M., and Simpson, J. (1984). "Self-Monitoring and Dating Relationships," Journal of Personality and Social Psychology, 47: 1281-1291.

Snyder, M. and Gangestad, S. (1982). "Choosing the Social Situation: Two Investigations of the SelfMonitoring Process," Journal of Personality and Social Psychology, 43: 123-135.

Snyder, M. (1974). "The Self -Monitoring of Expressive Behavior," Journal of Personality and Social Psychology.

Tangney, J. P. (1992). "Situational Determinants of Shame and Guilt in Young Adulthood," Personality and Social Psychology Bulletin, 18: 189-206.

Tangney, J.P., Burggraf, S.A., and Wagner, P.E. (1995). "Shame-Proneness, Guilt-Proneness, and Psychological Symptoms," in J.P. Tangney, and K.W. Fischer (eds.), Self-Conscious Emotions: The Psychology of Shame, Guilt, Embarrassment, and Pride: 343-367. New York: Guilford Press.

Thoits, P.A. (1989). "The Sociology of Emotions," in W. R. Scott and J. Blake (eds.), Annual Review of Sociology: 317-342.15 Palo Alto, CA: Annual Reviews.

\section{APENDIX (A)}

1. My behavior is usually an expression of my true inner feelings, attitudes and beliefs. (OD)

2. At parties and social gatherings, I do not attempt to say things that others will like. (OD)(b)

3. I can make impromptu speeches even on topics about which I have almost no information. (A)

4. When I am uncertain how to act in a social situation, I look to the behavior of others for cues. (OD)

5. I would probably make a good actor. (A)

6. I rarely need the advice of my friends to choose movies, books, or music. (OD) (b)

7. In a group of people I am rarely the center of attention. (EX) (b)

8. Indifferent situations and with different people, often act like very different persons. (OD) (b)

9. I am not particularly good at meeting other people like me. (EX) (b)

10. Even if I am not enjoying myself, I often pretend to be having a good time. (OD)

11. I am not always the person I appear to be. (OD)

12. I would not change my opinions (or the way I do things) in order to please someone else or win their favor. (OD) (b)

13. I have considered being an entertainer. (A) 
14. I have never been good at games like charades or improvisational acting. (A)

15. I have trouble changing my behavior to suit different people and different situation. (EX) (b)

16. At a party I let others keep the jokes and stories going. (EX) (b)

17. I feel a bit awkward in company and do not show up quite so well as I should. (EX) (b)

18. I may deceive people by being friendly when I really dislike them (OD)

b. Items reversed for scoring

OD: Other-directedness

A: Acting

EX: Extroversion

\section{APENDIX (B)}

\section{GUILT}

\section{Impersonal transgression}

1. Cheating on an exam and not getting caught.

2. Receiving too much change and keeping it.

3. Secretly taking office supplies home for personal use.

4. Successfully exaggerating your damage/loss in settling a dispute.

5. Successfully lying about your qualifications to get a job.

6 Stealing something from a store without anyone else finding out.

\section{Harm to another person}

7. As manager, retaining working conditions known to be harmful to employees' health.

8. Allowing someone else to be blamed for something you did.

9. Repeating damaging gossip about someone that you know is untrue.

10. Being unintentionally rude to a person you don't know, later realizing how hurt he/she was.

11. Failing to help someone you know is in trouble when you could have been of help.

12. Pretending more affection for someone than you really feel in order to exploit him/ her.

\section{Trust / oath violation}

13. Inadvertently revealing something about a person that he/she told you confidentially.

14. Giving false testimony in a trail, though you are not caught.

15. Continually making promises to a close friend, but failing to keep them.

\section{SHAME}

\section{Social impropriety}

16. Unconsciously eating with your fingers at an upscale restaurant, as other diners stare.

17. Making a scene at a corner of a busy business district.

18. Going to a party in casual clothes and finding that everyone else is dressed up. 
19. Calling someone to whom you have just been introduced by the wrong name.

20. After having dinner at an elegant restaurant, you burp quite loudly.

21. At a party, you tell a new acquaintance a risqué/ dirty joke and many are offended by it.

22. Getting drunk and making a fool of yourself in public.

23. Getting so bored listening to someone talk that you tell the person to shut up.

24. Spilling a plate full of food at a buffet dinner.

25. Your home is very messy and unexpected guests arrive.

\section{Exposed inadequacy}

26. Giving a talk on a topic you're supposed to know well and having someone in the audience demonstrate that you are factually wrong.

27. Stumbling and stuttering in an oral presentation and the instructor openly uses yours as an example of a poor presentation.

28. Finding out your clothes have become disarranged, exposing a part of you that is usually covered 29. Unwittingly making a remark disparaging to a minority group in front of a member of that group. 30. Strongly defending a point of view in a discussion to learn later you were incorrect. 